\title{
INJUNCTIVE RELIEF AGAINST MUNICIPALITIES UNDER SECTION 1983
}

In 1961 the Supreme Court handed down a landmark decision firmly endorsing a federal statutory remedy for the deprivation of rights secured by the Constitution or laws of the United States. Interpreting broadly the phrase, "under color of any statute," the Court in Monroe v. Pape ${ }^{1}$ held that section $1983^{2}$ creates a cause of action against police officers acting both unconstitutionally and beyond the authority of any state or local law. During the decade since Monroe, civil suits under section 1983 have proliferated.

Although the Monroe Court permitted recovery against the individual officers acting unconstitutionally, it affirmed the dismissal of the suit against the city of Chicago. ${ }^{3}$ The Court rejected arguments raising the general ineffectiveness of private remedies against police officers and other municipal agents, ${ }^{4}$ and relied exclusively on the legislative debates surrounding the defeat of a proposed amendment to the Civil Rights Act. The Court concluded that:

The response of the Congress to the proposal to make municipalities liable for certain actions being brought within federal purview by the Act of April 20, 1871, was so antagonistic that we cannot believe that the word "person" was used in this particular Act to include them. ${ }^{5}$

Subsequent lower court decisions have dealt summarily with damage actions against municipalities, ${ }^{6}$ and attempts to distinguish or dilute the Monroe prohibition against such actions have been largely unsuccessful. For example, in Brown v. Tozon of Caliente, ${ }^{7}$ the plaintiff

\section{U.S. 167 (1961).}

242 U.S.C. $\$ 1983$ (1964). Referred to as R.S. $\$ 1979$ in Monroe, this section provides:

Every person who, under color of any statute, ordinance, regulation, custom, or usage, of any State or Territory, subjects, or causes to be subjected, any citizen of the United States or other person within the jurisdiction thereof to the deprivation of any rights, privileges, or immunities secured by the Constitution and laws, shall be liable to the party injured in an action at law, suit in equity, or other proper proceeding for redress.

3365 U.S. at 192.

4 Id. at 191.

5Id.

6 See, e.g., Bright v. Bishop, 398 F.2d 804 (9th Cir. 1968) ; Wallach v. City of Pagedale, 359 F.2d 57 (8th Cir. 1966); Blume v. City of Deland, 358 F.2d 698 (5th Cir. 1966); Spampinato v. City of New York, 311 F.2d 439 (2d Cir. 1962).

7392 F.2d 546 (9th Cir. 1968). 
argued that Monroe only incorporated the doctrine of sovereign immunity into section 1983. Thus when the state waived immunity for its municipalities, it also removed the bar to actions under the federal statute. $^{8}$ The Ninth Circuit disagreed:

The Supreme Court having considered the Civil Rights Act, and having held municipalities were not liable under it, we cannot see how any action by the state . . . abolishing sovereign immunity . . . can bring about a different reading or different result to Monroe v. Pape . . . ${ }^{9}$

Judicial interpretation has expanded the scope of the statutory immunity beyond cities to other bodies politic, ${ }^{10}$ including township commissioners, ${ }^{11}$ a county board of education, ${ }^{12}$ a city police department, ${ }^{13}$ and a city hospital. ${ }^{14}$ Essentially, those bodies exercising the powers and performing the functions of local government may not be held liable for damages because a judgment against a governing body would have to be satisfied from the public treasury. ${ }^{15}$

But the status of municipal immunity in cases seeking injunctive relief is unsettled. An injunction against the municipality may be the only effective way to restrain a particular act or plan of action by a municipal governing body or administrative agency. For example, if the city council denies a building permit or zoning variance because of an applicant's race, an injunction should run to the local governing

8 Id. at 547.

9 Id. at 548 .

10 States and counties have been consistently held immune from suits for damages under $\$ 1983$. See, e.g., United States $e x$ rel. Gittlemacker v. County of Philadelphia, 413 F.2d 84 (3d Cir. 1969), cert. denied, 396 U.S. 1046 (1970) ; Williford v. California, 352 F.2d 474 (9th Cir. 1965); United States ex rel. Lee v. Illinois, 343 F.2d 120 (7th Cir. 1965); Garrison v. County of Bernalillo, 338 F.2d 1002 (10th Cir. 1964).

11 Johnson v. Hackett, 284 F. Supp. 933 (E.D. Pa. 1968) ; Roberts v. Trapnell, 213 F. Supp. 47 (E.D. Pa. 1962).

12 Patton v. Bennett, 304 F. Supp. 297 (E.D. Tenn. 1969).

13 United States ex rel. Lee v. Illinois, 343 F.2d 120 (7th Cir. 1965).

14 United States ex rel. Gittlemacker v. County of Philadelphia, 413 F.2d 84 (3d Cir. 1969).

15 See Roberts v. Trapnell, 213 F. Supp. 47 (E.D. Pa. 1962). In Roberts, a suit against the commissioners of Lower Merion Township was dismissed for failure to state a claim upon which relief could be granted. Dismissal was deemed necessary under the rule of Monroe because the commissioners held the corporate power of the township. Difficulties may arise in applying this rationale to suits against individual city officials because $\$ 1983$ was obviously intended to apply to deprivations of rights by individuals acting under color of state authority. Monroe v. Pape, 365 U.S. 167 (1961); Winters v. Miller, 306 F. Supp. 1158, 1163 (E.D.N.Y. 1969). Perhaps Monroe permits damage actions only against municipal officers sted in their individual rather than official capacities. In any event, actions against individual officers which in effect seek recovery from the local government are contrary to Monroe. See Westberry v. Fisher, 309 F. Supp. 12, 18 (D. Me. 1970). 
body itself to be most effective. ${ }^{16}$ Relief against the individual members of the council might not bind their successors in office or might not reach the administrative agents responsible for implementing final orders of the council. ${ }^{17}$ Furthermore, joinder of all parties may prove unduly cumbersome.

If the plaintiff seeks to enjoin harassment by municipal law enforcement officers, ${ }^{18}$ an injunction against the municipality offers him blanket protection. The plaintiff may be unable to identify the policemen directly responsible for past harassment, or they may be too numerous to join as parties. Injunctive relief against those individuals would undoubtedly not reach policemen uninvolved in previous deprivations of civil rights. An injunction issued to the police commissioner would prevent authorized harassment but might not include police officers acting contrary to department policy and beyond the control of the commissioner. A decree against the department would bind all the police but might not prevent civil rights violations by other law enforcement agencies such as the sheriff's office. Equitable relief against the municipality, however, provides the broadest possible protection for civil rights secured by the Constitution and laws of the United States because it reaches every city official or employee with notice of the injunction who might violate those rights.

In view of the shared interests of police and prosecuting attorneys, it is naive to rely on the possibility of criminal sanctions as a deterrent to unconstitutional conduct. ${ }^{19}$ In addition, civil actions based on theories of tort law have proved largely ineffective in preventing abusive conduct by government officials, ${ }^{20}$ in part because of the nature of the injuries suffered by parties alleging deprivation of constitutional rights. As one observor has noted:

The vast majority of police transgressions are acts of harassment and bullying which never lead to prosecutions-unwarranted arrests, illegal searches, unreasonable disruptions of harmless conduct, verbal insults. Such violations leave no visible scars; the victim usually does not suffer bodily injury or loss of property. Yet to the individual victim these acts constitute serious intrusions upon his privacy, dignity, and security. ${ }^{21}$

16 See Dailey v. City of Lawton, 425 F.2d 1037 (10th Cir. 1970).

17 See FEn. R. Civ. P. 65(d).

${ }^{18}$ See Schnell v. City of Chicago, 407 F.2d 1084 (7th Cir. 1969).

19 Note, The Federal Injunction as a Remedy for Unconstitutional Police Conduct, 78 Y ALE L.J. 143, 144 n.9 (1968). See also Schwartz, Complaints Against the Police: Experience of the Community Rights Division of the Philadelphia District Attorney's Office, 118 U. PA. L. REv. 1023 (1970).

20 Note, supra note 19, at 144.

21 Id. 143-44 (footnote omitted). 
Thus, injunctive relief is essential to the effective enforcement of guaranteed rights because of the breadth of the protection necessary and the drawbacks of other methods of enforcement. ${ }^{22}$

But injunctive relief under section 1983 may be unavailable and suits directly under the Constitution for such relief have not been widely recognized. ${ }^{23}$ Because the petitioners in Monroe sought damages from the city of Chicago for alleged deprivation of fourteenth amendment rights, the Court was not called upon to resolve the question of availability of injunctive relief under the statute. Yet in a somewhat enigmatic footnote, the Court may have precluded injunctive as well as damage actions:

In a few cases in which equitable relief has been sought, a municipality has been named, along with city officials, as defendant where violations of 42 U.S.C. $\$ 1983$ were alleged. . . . The question dealt with in our opinion was not raised in those cases, either by the parties or by the Court. Since we hold that a municipal corporation is not a "person" within the meaning of $\S 1983$, no inference to the contrary can any longer be drawn from those cases. ${ }^{24}$

22 One commentator has noted the utility of injunctive relief in securing rights guaranteed by state civil rights acts:

A number of factors combine to make injunctive relief particularly appropriate to remedy infringement of an individual's civil rights. The traditional basis for the exercise of equity powers is inadequacy of the remedy at law. When criminal enforcement is lax or difficult to obtain, the legal remedy is, for all practical purposes, inadequate. And even when enforcement is adequate, the imposition of a criminal penaity is an unsatisfactory substitute for the actual enjoyment of the rights created by legislation. The award of monetary damages is equally unsatisfactory because of the nature of the personal right infringed. Not only are such damages difficult to assess, they cannot provide full compensation. Another factor of practical importance is the likelihood of a multiplicity of suits at law under those statutes which make a civil action available. Finally, the injunction offers the flexibility needed in dealing with a complex social problem.

Comment, Availability of Injunctive Relief Under State Civil Rights Acts, 24 U. CHI. L. REv. 174, 180 (1956).

23 If injunctive relief directly under the Constitution were available, the problem discussed herein would be less acute. A discussion of this possibility is beyond the scope of this Comment, but for an extensive treatment of the issues, see Hill, Constitutional Remedies, 69 CoLUM. L. REv. 1109 (1969). The Supreme Court may illuminate some of the issues involved when it decides Bivens v. Six Unknown Named Agents of the Fed. Bureau of Narcotics, 409 F.2d 718 (2d Cir. 1969), cert. granted, 399 U.S. 905 (1970). The lower court dismissed an action for damages under the fourth amendment after it had assumed jurisdiction under 28 U.S.C. $\$ 1331$ (1964). The resolution of this case should explicitly determine whether the Constitution creates a cause of action in a private citizen for governmental violations of constitutional rights. If it does, 28 U.S.C. $\$ 1343(3)$ (1964) might provide the jurisdictional basis for an action for injunctive relief.

However this question is resolved, suits under $\$ 1983$ will remain important, for that section also permits redress of rights secured by statutes of the United States. In addition, $\$ 1983$ might be read as a congressional limitation on suits under the Constitution embraced by the statute. Furthermore, a reinterpretation of $\$ 1983$ and Monroe to permit injunctive relief against municipalities avoids difficult and pervasive constitutional issues which the Court might prefer to bypass.

24365 U.S. at 191 n.50. 
Because the Monroe Court resolved the issue of municipal liability through a definition of the statutory term "person," it would seem logically consistent to interpret Monroe as prohibiting any action whatsoever against municipal bodies: a municipality not a "person" in a damages suit does not become a "person" when the action is equitable under the same statute. ${ }^{25}$

But this view of section 1983 and Monroe has not been uniformly adopted by the lower federal courts. ${ }^{26}$ This Comment will briefly note subsequent decisions interpreting Monroe, and will then reexamine the legislative history of section 1983 to determine if any distinction between damages and injunctive relief is tenable in light of that history. Finally, this Comment will suggest a rationale permitting injunctive relief against municipalities consistent with the prohibition against actions for damages.

Several lower federal courts-at least one deriving its authority squarely from footnote fifty of Justice Douglas' opinion; ${ }^{27}$ others, from the Court's broad holding that a municipality is not a "person" within the contemplation of section $1983^{28}$-have dismissed suits for equitable relief against municipalities. Yet, other courts, notably the Seventh Circuit, have distinguished between section 1983 suits for damages against municipalities and those seeking injunctive relief. ${ }^{29}$ In Adams v. City of Park Ridge, ${ }^{30}$ the Seventh Circuit held that the rationale of

25 Two Supreme Court cases since Monroe may cast some doubt on this interpretation of footnote fifty in the majority opinion. In Turner v. City of Memphis, 369 U.S. 350 (1962), the Court held in a per curiam opinion that an injunction should issue to restrain the city from maintaining a segregated restaurant in the Memphis Municipal Airport. The opinion noted briefly that the action had been initiated under $\$ 1983$, but did not discuss the "personality" of the city or cite Monroe. Likewise, in Tinker v. Des Moines Independent Community School Dist., 393 U.S. 503 (1969), the Court treated the school district as a proper party under $\$ 1983$. Once again the opinion did not discuss or even mention Monroe. Perhaps these cases may be explained by the language of footnote fifty: "The question dealt with in [Monroe] . W was not raised in those cases, either by the parties or by the Court." 365 U.S. at 191 n.50. Because the Court did not discuss the municipality as a "person," and because subsequent lower federal court decisions are in conflict, compare cases cited notes $27-28$ infra, with cases cited note 32 infra, these two cases have not put the issue to rest.

26 See notes 30-32 infra \& accompanying text.

27 In Deane Hill Country Club, Inc. v. City of Knoxville, 379 F.2d 321 (6th Cir.), cert. denied, 389 U.S. 975 (1967), a suit for damages and injunctive relief against the enforcement of a municipal ordinance and state statute, the court recognized that Monroe involved only an action for damages but nevertheless concluded that footnote fifty disposed of the issue of equitable relief. Id. at 324 .

2s See, e.g., Diamond v. Pitchess, 411 F.2d 565 (9th Cir. 1969); Johnson v. Hackett, 284 F. Supp. 933 (E.D. Pa. 1968); Sutton v. City of Philadelphia, 286 F. Supp. 143 (S.D.N.Y. 1968); Fowler v. United States, 258 F. Supp. 638, 646-47 (C.D. Cal. 1966) ; Pinkus v. Arnebergh, 258 F. Supp. 996 (C.D. Cal. 1966).

29 While recognizing that injunctions by their terms may either prohibit or compel action, this Comment deals chiefly with prohibitory injunctions-those restraining unconstitutional acts. Injunctions which compel a municipality to appropriate funds or to take specific, expensive action closely resemble damage actions in practical effect, and will not be treated herein.

30293 F.2d 585 (7th Cir. 1961). 
Monroe was inapplicable to injunction actions. The court found in the factual basis for the Supreme Court's decision

several inherent reasons for excluding municipalities from liability for damages, such as tunauthorized misconduct of the officers, lack of power of [a] city to indemnify plaintiffs for such misconduct, and a city's governmental immunity in the exercise of its police powers . . . . ${ }^{31}$

Finding these reasons inapposite when an injunction alone was at issue, the court restrained the enforcement of a city ordinance as repugnant to the fourteenth amendment; in the Seventh Circuit an injunction will issue against a municipality under section $1983 .^{32}$

Should the Supreme Court be called upon to resolve this conflict among circuits and state precisely the breadth of the Monroe prohibition, it may well wish to reexamine the legislative history surrounding the enactment of the Act of April 20,1871-the origin of section 1983. The Monroe majority particularly stressed the debates on the Sherman amendment ${ }^{33}$ providing for recovery of damages against mu-

31 Id. at 587.

32 See Schnell v. City of Chicago, 407 F.2d 1084 (7th Cir. 1969); Sanberg v. Daley, 306 F. Supp. 277, 278 n.3 (N.D. Ill. 1969) (dictum).

Other courts have also expressed the view that the Monroe prohibition is inapplicable to suits for injunctive relief. See Harkless v. Sweeny Independent School Dist., 427 F.2d 319, 321-23 (5th Cir.), petition for cert. filed, 39 U.S.L.W. 3073 (U.S. Aug. 19, 1970) (No. 561); Dailey v. City of Lawton, 425 F.2d 1037 (10th Cir. 1970) ; United States v. City of Jackson, 318 F.2d 1, 11 (5th Cir. 1963) (dictum); Atkins v. City of Charlotte, 296 F. Supp. 1068 (W.D.N.C. 1969); Service Employees Int'l Union v. County of Butler, 306 F. Supp. 1080 (W.D. Pa. 1969) ; Prisoners' Rights Under Section 1983, 6 CRIM. L. BuLr. 237, 263 (1970). In Dailey, the court concluded that footnote fifty of Justice Douglas' opinion did not compel a conclusion of absolute municipal immunity.

We read that footnote as differentiating between actions for damages and actions for equitable relief and as intending no bar to equitable actions for injunctive relief against invasions of a plaintiff's federal constitutional rights by municipal action.

425 F.2d at 1038.

33 As originally passed by the Senate, the amendment read:

That if any house, tenement, cabin, shop, building, barn, or granary shall be unlawfully or feloniously demolished, pulled down, burned, or destroyed, wholly or in part, by any persons riotously and tumultuously assembled together; or if any person shall unlawfully and with force and violence be whipped, scourged, wounded, or killed by any persons riotously and tumultuously assembled together; and if such offense was committed to deprive any person of any right conferred upon him by the Constitution and laws of the United States, or to deter him or punish him for exercising any such right, or by reason of his race, color, or previous condition of servitude, in every such case the inhabitants of the county, city, or parish in which any of the said offenses shall be committed shall be liable to pay full compensation to the person or persons damnified by such offense if living, or to his legal representative if dead; and such compensation may be recovered by such person or his representative by a suit in any court of the United States of competent jurisdiction in the district in which the offense was committed, to be in the name of the person injured, or his legal representative, and against said county, city, or parish; and execution may be issued on a judgment rendered in such suit, and may be levied upon any property, real or 
nicipalities and counties for property losses and personal injuries resulting from civil disturbances. The Court accurately and succinctly described the events leading to the defeat of the amendment:

When the bill that became the Act of April 20, 1871, was being debated in the Senate, Senator Sherman of Ohio proposed an amendment which would have made "the inhabitants of the county, city, or parish" in which certain acts of violence occurred liable "to pay full compensation" to the person damaged or his widow or legal representative. The amendment was adopted by the Senate. The House, however, rejected it. The Conference Committee reported another version. The House rejected the Conference report. In a second conference the Sherman amendment was dropped 34

But the reasons for the rejection are not apparent from the Court's opinion. ${ }^{35}$

personal, of any person in said county, city, or parish; and the said county, city, or parish may recover the full amount of said judgment, cost, and interest from any person or persons engaged as principal or accessory in such riot, in an action in any court of competent jurisdiction.

Cong. Grobe, 42d Cong., 1st Sess. 704 (1871). Although amended in conference, few substantive changes were made in the first portion of the provision. In addition to adding an explicit requirement of intent and making several minor word changes, the revised Sherman amendment contained additional language recognizing the liability of the municipality only after the judgment was not satisfied by the actual wrongdoers:

[A]ny payment of any judgment, or part thereof unsatisfied, recovered by the plaintiff in such action, may, if not satisfied by the individual defendant therein within two months next after the recovery of such judgment upon execution duly issued against such individual defendant in such judgment, and returned unsatisfied, in whole or in part, be enforced against such county, city, or parish, by execution, attachment, mandamus, garnishment, or any other proceeding in aid of execution or applicable to the enforcement of judgments against municipal corporations; and such judgment shall be a lien as well upon all moneys in the treasury of such county, city, or parish, as upon the other property thereof. And the court in any such action may on motion cause additional parties to be made therein prior to issue joined, to the end that justice may be done. And the said county, city, or parish may recover the full amount of such judgment, by it paid, with costs and interest, from any person or persons engaged as principal or accessory in such riot, in an action in any court of competent jurisdiction. And such county, city, or parish, so paying, shall also be subrogated to all the plaintiff's rights under such judgment.

Id. 749.

Representative Shellabarger explained the effect of this amendment as follows:

First, it does make a liability for a class of damages or injuries which result from riotous disorders. . . .

Next, the amendment agreed to by the committee of conference completely changes the remedy granted for the mischief, by preventing a claimant entitled to recover from resorting to property of individuals at all and confining his right of recovery to the county or city in which the mischief was done. - Then, as to the method of enforcement of the judgment when recovered, it provides they shall have the remedies applicable in cases of judgments against corporations of this municipal character.

Id. 751 . 
The debates make clear that opponents of the amendment were concerned primarily with two related but distinct problems: first, whether Congress had the power to compel a local government to raise taxes to pay a judgment against it; and second, whether Congress could make a municipality liable for failing to prevent civil disorders which the state had not empowered it to prevent. As Senator Trumbull stated:

I do not know where the Government of the United States gets the constitutional authority to go into the States and establish police regulations. I do not know where the Government of the United States gets the authority to go into the county in which I live, or the city or the town where I may live, and compel it to raise taxes to pay judgments, or where it gets the authority to take money out of the treasury of the county or town. I know of no such constitutional authority. ${ }^{36}$

Accepting the generally held constitutional premise that Congress could not impose a tax upon the states, ${ }^{37}$ opponents of the Sherman amendment argued that it was also beyond the power of the United States to inflict liabilities and resulting taxes upon a municipal corporation or other integral part or creature of a state. ${ }^{38}$ Representative Poland observed:

I did understand from the action and vote of the House that the House had solemnly decided that in their judgment Congress had no constitutional power to impose any obligation upon county and town organizations, the mere instrumentality for the administration of State law. ${ }^{38}$

Opponents of the amendment challenged its wisdom as well as its constitutionality. Predicting the dire results of a law permitting recovery

34365 U.S. at 188-89 (footnotes omitted).

35 The Court makes a general reference to doubts entertained by some members of Congress concerning Congress' power to impose civil liability upon municipalities. Id. at 190 .

36 Cong. Globe, 42d Cong., 1st Sess. 759 (1871) ; see id. 762 (remarks of Senator Stevenson).

37 See Collector v. Day, 78 U.S. (11 Wall.) 113 (1871). This case held that the national government could not constitutionally tax the salary of a state judge. Decided shortly before the debates on the Sherman amendment, Day was cited with approval by opponents of the amendment during those debates. See, e.g., CONG. GLOBE, 42d Cong., 1st Sess. 795 (1871) (remarks of Representative Blair); id. 764 (remarks of Senator Davis).

38 See Cong. GLoBE, 42d Cong., 1st Sess. 795 (remarks of Representative Blair) ; id. 764 (remarks of Senator Casserly).

39 Id. 804. 
of damages from cities, members of Congress envisioned absolute congressional control of cities ${ }^{10}$ and the eventual destruction of smaller municipalities. ${ }^{41}$ These congressmen and senators feared with Senator Thurman that a lien on county or town property to satisfy judgments would halt the operation of the local government by diverting funds earmarked for essential services toward payment of the federally imposed obligations. ${ }^{42}$ A few may have agreed with Senator Casserly that the amendment would authorize the attachment and sale of the courthouse, jail, or other municipal property to pay the judgment. ${ }^{43}$ In spite of attempts by proponents to characterize the Sherman amendment as a mutual insurance provision, ${ }^{44}$ most members of Congress apparently viewed it as an attempt to punish criminally a subdivision of the state for acts done within its boundaries. ${ }^{45}$

Congress also feared that the amendment would impose an affirmative duty on the municipality or county to prevent civil disturbances which might cause personal injury or property damage regardless of whether the state had empowered the local body to prevent such disturbances. ${ }^{46}$ In effect, the amendment would compel states to exercise their police powers in a particular manner, ${ }^{47}$ a result thought to be unauthorized by the fourteenth amendment, ${ }^{48}$ the constitutional basis for the legislation. And, of course, the city would be required to pay for damages it could not prevent without adequate police powers granted by the state. ${ }^{49}$

The Sherman amendment and its opponents focused primarily on damage actions against municipalities, and the legislative history should be read accordingly. By allowing equitable remedies under the Act of April 20,1871, Congress would not have imposed a direct tax on local governments because prohibitory injunctions do not generally require the appropriation of funds and the consequent depletion of the public treasury. ${ }^{50}$ Fears that counties might be bankrupted or town jails

40 See id. 788-89 (remarks of Representative Kerr).

41 See id. 763 (remarks of Senator Casserly).

42 See id. 772.

43 See id. 763.

44 See id. 792 (remarks of Representative Butler).

45 See id. 788 (remarks of Representative Kerr); id. 777 (remarks of Senator Frelinghuysen).

${ }^{46}$ See id. 791 (remarks of Representative Willard).

47 See id. 795 (remarks of Representative Blair).

48 See id. 777 (remarks of Senator Frelinghuysen).

49 See id. 773 (remarks of Senator Thurman). Senator Thurman quoted a Kentucky statute which rendered municipalities liable for riot damage and he noted particularly that the city would be liable only if it had the ability to prevent the damage.

50 See note 29 supra. 
attached to satisfy judgments under the amendment are groundless when applied to injunction actions. Similarly, injunctions restraining deprivations of rights secured by the Constitution or laws of the United States would not impose duties on the local government which it is not empowered to fulfill. A prohibitory injunction under section 1983 imposes no further obligation than that the municipality act within the limits of its authority: the municipality is not required to act beyond its power-it is required to refrain from so acting. ${ }^{51}$

Because the reasons underlying the defeat of the Sherman amendment do not apply to injunctive relief, the Forty-Second Congress probably intended to incorporate into section 1983 whatever injunctive remedy was then available in federal courts against municipalities. The law in 1871 was clear: municipal corporations could be enjoined in federal courts.

Textwriters of the late nineteenth century agreed that municipalities might be enjoined in courts of equity. Writing in 1872, Judge John Dillon noted :

[S] ince these corporations hold their powers in trust for the public benefit, and since the remedy by injunction or by bill in equity is often more efficacious than any other to restrain and correct municipal abuses, the spirit of the later cases is to favor a relaxation, rather than a strict application of the rule ... which denies the right to go into equity if there be a plain and full remedy at law. . . . Generally speaking, equity will interfere in favor of, or against, municipal corporations, on the same principles by which it is guided in other cases. ${ }^{.2}$

At the very least, courts of equity had jurisdiction to enjoin municipal corporations when there existed no adequate remedy at law-and probably a less stringent standard applied. ${ }^{53}$ A leading authority on injunctive relief also recognized such jurisdiction:

The jurisdiction of courts of equity to restrain the proceedings of municipal corporations, at the suit of citizens and taxpayers, where such proceedings encroach upon private rights and are productive of irreparable injury, may be regarded as well established. ${ }^{54}$

51 See Penn v. Stumpf, 308 F. Supp. 1238, 1241 (N.D. Cal. 1970) (no public treasury expense when injunction is sought; Congress never contemplated immunity of municipal officials from suits for injunctions under Civil Rights Act). (1872).

$52 \mathrm{~J}$. Dillon, Treatise on the Law of Municipal Corporations $\$ 728$, at 678

53

Injunction is generally recognized and used as an appropriate remedy to be invoked both for and against the municipality for the protection of public and private rights, when irremediable loss or damage is menaced.

R. Cooley, Handbook of the Law of Municipal Corporations $\$ 161$, at 488 (1914).

54 J. High, A Treatise on the LaW of Injunctions $\$ 783$, at 463 (1874). 
Unquestionably, then, leading scholars at the time of the enactment of the 1871 Civil Rights Act recognized equitable jurisdiction over municipal corporations and treated injunctive relief to protect private rights as a part of that jurisdiction.

An 1870 decision of the Supreme Court, Dows v. City of Chicago, ${ }^{55}$ reaffirmed this jurisdiction in the federal courts. Although refusing to restrain the city of Chicago from collecting its taxes, the Court stated:

No court of equity will, therefore, allow its injunction to issue to restrain [the municipal officers'] action, except where it may be necessary to protect the rights of the citizen whose property is taxed, and he has no adequate remedy by the ordinary processes of the law. It must appear that the enforcement of the tax would lead to a multiplicity of suits, or produce irreparable injury, or where the property is real estate, throw a cloud upon the title of the complainant, before the aid of a court of equity can be invoked. ${ }^{58}$

Lower federal courts also invoked this equity power to enjoin wrongful acts by municipal corporations. In Lambell v. Washington, ${ }^{57}$ the circuit court enjoined a municipality from enforcing an ordinance granting a monopoly to plaintiff's competitor. The court invoked traditional equitable principles to reach its decision. ${ }^{58}$ Similarly, in Coulson v. Portland, , $^{59}$ the court enjoined the city of Portland from collecting its taxes under an invalid ordinance and from using public monies to fund a private debt. Federal cases after 1871 reaffirmed the power of the federal courts to issue injunctions to restrain municipal corporations. ${ }^{60}$

Although their remarks were generally directed towards suits for damages, several congressmen and senators of the Forty-Second Congress recognized that municipalities were amenable to suit in the courts of the United States. ${ }^{61}$ Clearly, Congress was aware of a general jurisdiction over local governments, and undoubtedly its members were also aware that federal courts had power to issue injunctions restraining municipal actions.

5578 U.S. (11 Wall.) 108 (1870).

$56 I d$. at 110.

5714 F. Cas. 1043 (No. 8,025) (C.C.D.C. 1841).

$58 \mathrm{Id}$. at $1044-45$.

596 F. Cas. 629 (No. 3,275) (C.C.D. Ore. 1868).

60 See, e.g., Phillips v. Detroit, 19 F. Cas. 512 (No. 11,101) (C.C.E.D. Mich. 1877) ; Ranger v. New Orleans, 20 F. Cas. 269 (No. 11,564) (C.C.D. La. 1875).

61 See Cong. GLoBE, 42d Cong., 1st Sess. 777 (1871) (remarks of Senator Sherman); see id. 821 (remarks of Senator Sherman); id. 788 (remarks of Representative 
As some courts have sensed, the holding in Monroe was broader than warranted by its facts or by the legislative history on which it was based. The reasons for the defeat of the Sherman amendment-that it would impose a direct tax on municipal corporations and would permit Congress to impose duties on cities and counties which they might not be empowered to carry out-are inapplicable to suits for prohibitory injunctions. Thus, Congress did not intend to prohibit such suits in the federal courts, but rather sought to permit those courts to exercise what jurisdiction they had in 1871 over municipal corporations. The federal courts had general equity powers to issue injunctions against municipalities. Thus, the reasoning of Monroe does not apply to actions for prohibitory injunctions and such relief may be granted to restrain municipal corporations.

This Comment has focused on prohibitory injunctions because they do not ordinarily require a municipality to appropriate funds, or impose obligations on the city to use its police power in a particular, affirmative manner. Mandatory injunctions, on the other hand, may sometimes necessitate the type of affirmative action Congress refused to require of municipalities: such injunctions may be impermissible under Monroe. In some instances this problem may be side-stepped by phrasing a prayer for relief in prohibitory terms. For example, a federal court may not be empowered to require a municipality to make affirmative renovations in a city jail where the conditions constitute cruel and unusual punishment; but the court could enjoin the city from imprisoning persons in such a jail in violation of their constitutional rights. The city would rather renovate the jail than release the prisoners; but then the municipality, not the court, would be compelling the affirmative action. To avoid such abstract considerations, however, a court might well choose as a matter of propriety not to issue such an injunction, and simply declare the existence of the unconstitutional condition. In any event, Monroe need not be read to preclude the federal courts from issuing any injunction against municipal corporations under section 1983. A viable distinction exists between legal and injunctive relief, and the federal courts should not hesitate to recognize it. 